\title{
Private order building: the state in the role of the civil society and the case of FIFA
}

\author{
Branislav Hock ${ }^{1,3}$ (1) S Suren Gomtsian ${ }^{2,3}$
}

Published online: 13 April 2018

(c) The Author(s) 2018

\begin{abstract}
There is an ever-present danger that a private association may evolve into an enterprise with an elitist structure that extensively exploits its powers. While it is well known that the key role in limiting the excessive powers of state elites belongs to civil society, the question of policing the elites of monopolistic private orders is understudied. We use the case of the Fédération Internationale de Football Association's (FIFA) private order to illustrate how private orders evolve under constraints imposed by public orders. Although private ordering has advantages compared to public ordering, much of the credit for the success of FIFA's private order goes to the state. Regulatory privileges granted to FIFA, and the refusal to intervene widely in FIFA's affairs, have made private ordering possible in the first place. The challenge is, however, that private association capture by powerful interest groups can easily limit advantages of private ordering. In this situation, the proper role of the state is to act in the role of civil society by employing strategic interventions to help the private order deal with its governance failures without endangering the private order's existence. Accordingly, when the power within a monopolistic private membership association becomes heavily imbalanced, it invites the state to intervene in an attempt to restore the lost balance. However, opening the door to the state-as in the case of so-called FIFA-gate-increases the danger that other and greater interventions will undermine the existence of the private order and remove its advantages.
\end{abstract}

Keywords Private ordering · Public-private governance · Organizational behavior · Civil society · Corruption · FIFA · Football

\section{Introduction}

An earlier version of this Article was presented at the 6th SIEL PEPA Conference 2017 at Tilburg University and the ISLJ Annual International Sports Law Conference 2017 at TMC Asser Instituut in The Hague.

An earlier draft of the Article received the award for the best paper presented at the ISLJ Annual International Sports Law Conference 2017.

Branislav Hock

branislav.hock@port.ac.uk

Suren Gomtsian

s.gomtsyan@leeds.ac.uk

1 Lecturer in Counter Fraud Studies, Institute of Criminal Justice Studies, University of Portsmouth, Portsmouth, UK

2 Lecturer in Business Law, Centre for Business Law and Practice, School of Law, University of Leeds, Leeds, UK

3 Tilburg Law and Economics Center (TILEC), Tilburg, The Netherlands
States and supra-national organizations, like the European Union (EU), have always been considered as the primary candidates for building and maintaining institutional infrastructure that supports economic activity. They do this by dealing with undesirable monopoly, market power, and other market failures that plague the competitive trade of commodities and services. As a result, the traditional answer to these problems has always been that "there ought to be state regulation". Nevertheless, numerous private modes of governance-such as business, sport, and other member associations-provide institutional support for economic activity. Business and economic globalization, coupled with the rise of the freedom of contract and private dispute resolution bodies, has inevitably increased the role of private ordering. ${ }^{1}$

\footnotetext{
${ }^{1}$ See Ellickson (2016), p. 250 (noting that both legislators and judges commonly are inclined to give wide discretion to private orders).
} 
Indeed, private associations often step into the shoes of regulators and to offer institutional support with advantages that public ordering often lacks. ${ }^{2}$ Consider, for example, the private association's expertise, flexibility in decision-making and better knowledge of the involved actors. The superiority of these aspects of private associations results in institutions that are better suited to the needs of the involved actors. However, along with numerous advantages, private ordering also has problems. Private orders might, for example: become a hostage of powerful interest groups; pay inadequate attention to violations of human rights; and be plagued by corruption. ${ }^{3}$ These failures of private ordering often lead to calls by the public, community groups, and businesses, for intervention, which can even include restoring public prerogative over areas subject to the rule of private orders. Both public and private orders are then in a difficult position. The former must decide whether and how to intervene in private orders, and the latter how to prevent, and potentially address, such interventions.

While economic governance scholars have documented how and why the role of private ordering has increased, they have produced little research on the interaction between private orders, on the one hand, and states and supra-national organizations (public orders), on the other. ${ }^{4}$ Likewise, while much is known about the mechanisms that ensure the successful functioning of private orders, ${ }^{5}$ the role of public orders in the evolution of private orders is still unclear. This article offers a new insight to fill this knowledge gap.

This paper studies the role of public orders in the emergence and evolution of private orders. First, the paper introduces a model of interactions and then illustrates its application using the example of the private legal order created by FIFA - the world governing body of football. Fédération Internationale de Football Association, better known as FIFA, has long been associated with its ability to govern and commercialize the game of football, and, lately, also with large corruption scandals. ${ }^{6}$ FIFA thus exemplifies

\footnotetext{
${ }^{2}$ See Bernstein $(1992,2001)$ and Greif (1993), p. 542. For the discussion of the advantages of private ordering, see Sect. 2.1 below. 3 Leisinger (2009). We recognize that corruption is not only a problem of private ordering. States may be corrupt as well. Democratic states, however, have a system of check-and-ballances that tackle corruption. Private orders do not have such mechanisms, as a rule.

${ }^{4}$ Accordingly, the question as to when private modes of governance can fill the void left by public orders is fairly settled.

${ }^{5}$ Hadfield and Weingast (2012) (arguing that decentralized enforcement system based on a collective punishment mechanism is, to some extent, the necessary feature of any legal order; such system is an equilibrium provided that there is an institution classifying behavior as wrongful or not). See also Gibbons and Henderson (2012).

${ }^{6}$ Jennings (2011).
}

both the advantages of private ordering as well its failures. This makes FIFA's private order an ideal case for studying the role of public orders in the evolution of private orders. In this context, the paper illuminates some otherwise puzzling state practices, i.e., state's inconsistency in whether they tolerate alternative control of employment relations by sport associations, their anti-competitive behavior, and governance problems.

Our analysis indicates that public orders challenge private orders in cases of excess, especially in limiting the potential of powerful interest groups. ${ }^{7}$ Otherwise, public orders usually respect the freedom of private orders to selfregulate their activities and influence private orders by soft and indirect means. This is similar, we argue, to the case of nation states in which the key role in limiting excessive powers of elites belongs to the civil society. The analogythe state as the civil society-provides yet another unexplored perspective on the role that states have when intervening in private orders. ${ }^{8}$ These results, although illustrated using the example of FIFA, have implications for the successful functioning of private orders in general, be it business, sport, or any other member association.

The rest of this article is organized as follows. Part 2 sets up the landscape by (a) introducing the advantages and disadvantages of private ordering, (b) indicating the role public orders play in the emergence and evolution of private orders, and (c) identifying limitations of current research. Part 3 introduces a model of how private orders evolve under constraints provided by public orders. This part theorizes about the role that public orders play (and also should play) in the emergence and evolution of member associations. It is hypothesized that if a public order does not intervene directly into the constituency of a legitimate member association, such an order is, and will be, more effective in locking all involved actors. Part 4 applies this model to examine the private legal order of FIFA. At the end, we offer some conclusions.

\footnotetext{
${ }^{7}$ By power interest groups, we mean groups formed inside private orders to promote their own interests, thereby completely changing the legitimate nature of these orders.

${ }^{8}$ Civil society is broadly defined as "the process through which individuals", represented by various voluntary associations, "negotiate, argue, struggle against or agree with each other and with the centers of political and economic authority" Kaldor (2003), p. 585 (arguing that the definition of civil society has been constantly developing). Scholte (2004), p. 214 (defining civil society as "a political space where voluntary associations seek, from outside political parties, to shape the rules that govern one or the other aspect of social life").
} 


\section{Outside the legal-centric view: private ordering}

Undesirable monopoly and market power, negative externalities, the failure to provide public goods, and severe information asymmetries are the sources of market failures. $^{9}$ Market failures plague the competitive trade of commodities and services; hence, resources are not distributed based on their most valued use. Often when we face market failures and consider solutions for them, the prime candidate for intervention is the state. Accordingly, states sometimes replace or change some of the market properties, including its institutions. ${ }^{10}$ This classic statecentric paradigm has, however, been criticized for its failure to provide good order and workable arrangements in various circumstances. For example, the state's monopoly to regulate effectively cyber-crime and other transnational activities within its "territory" is a myth. ${ }^{11}$ It is documented that private orders can step in and offer institutional support in areas that are beyond the reach of the state. ${ }^{12}$ Typical instances include (1) private orders that predate modern states, such as private prosecution associations during the Industrial Revolution in England, ${ }^{13}$ (2) private orders in current-day developing countries where weak state institutions are insufficient to support economic activities, and (3) illegal underworld activities, such as pirate organizations ${ }^{14}$ and mafia, which obviously cannot rely on state-supplied laws. ${ }^{15}$ There are, however, also contemporary private orders, such as sport and business associations that successfully function along established states. These non-state modes of governance develop institutions that support order and cooperation. ${ }^{16}$ Their

\footnotetext{
${ }^{9}$ In economics, market failures are not socially desirable because they limit the establishment of 'general equilibrium', meaning a situation where "competitive forces have led to the equality of marginal benefit and marginal cost in the market for every single commodity and service". Cooter and Ulen (2012), p. 38.

10 Organization generally refers to an authority that can decide how formal institutions are structured and/or implement formal institutions. Institutions are then rules of the game, i.e. formal "constrains that structure political, economic and social interaction". See North (1991), p. 97. See also Acemoglu and Robinson (2005) and Greif (2006).

11 Ip 2011; See generally Nye and Keohane (1971); In the field of law and economics, see generally Katz (1996), p. 1754.

12 See Bernstein (1992), Greif (1993) and Ellickson (2016). However, the critical literature is doubting the actual prevalence of some private orders in the past, see Ogilvie and Carus (2014) (showing weaknesses in a number of stylized historical facts such as that the Glorious Revolution of 1688 lead to the sudden emergence of secure property rights).

${ }^{13}$ See Koyama (2012).

14 See Leeson (2009).

15 Milhaupt and West (2000).

16 Bernstein (1992, 2001) and Gomtsian (2017).
}

existence complicates our understanding of how to address market failures best.

\subsection{Advantages and problems of private ordering}

Private modes of governance are often better accustomed to provide good order and workable arrangements than the state. Research on economics of governance provides valuable insights into the functioning of private modes of governance. ${ }^{17}$ This scholarship identified the two main advantages of private ordering compared to public ordering. One is informational advantage in designing specialized rules of behavior and resolving the arising disputes in swift, qualified, and sometimes even less costly manner. Another is the responsiveness of the order to the needs of the involved actors owing to the greater involvement of the actors in the formation of the rules. These advantages stand behind the success of many private orders. ${ }^{18}$ This, however, does not imply that such private orders are necessarily efficient or legitimate. ${ }^{19}$

Indeed, it is equally true that private ordering is prone to two potential failures. First, private-order institutions are not necessarily the most efficient from the perspective of maximizing social welfare. Consider illegitimate private orders, such as $\mathrm{Ku}$ Klux Klan, that can be built on discrimination, racism, and other rationales that, if accomplished, lead to excessive costs for third parties. ${ }^{20}$ While such illegitimate orders may develop institutions ensuring internal cooperation and promoting common ends, such institutions create a net loss for society. ${ }^{21}$ Furthermore, cartel agreements between businesses, price signaling, misuse of power, and other activities that make markets less competitive-and therefore decrease the overall welfare of society-may be the most rational and efficient course of action for members of some private orders. ${ }^{22}$ Therefore, private ordering may create negative externalities that are undesirable for society at large.

Second, even if we disregard negative effects that private orders may inflict on third parties, powerful interests groups may make private orders rotten from inside, thereby

\footnotetext{
17 Williamson (2005).

18 Some argue that the key reason is that private orders are able to manage transactions more efficiently than the state would, see generally Posner (1996), pp. 1700-1701; Dixit (2004), pp. 32-48.

${ }^{19}$ Please note that the critical literature challenges the efficiency and legitimacy of private ordering, among many other see Claire Cutler (2010) and Calliess and Zumbansen (2010).

${ }^{20}$ Fukuyama (2000) Social Capital and Civil Society. IMF Working Paper No. 0074, p. 4.

${ }^{21}$ See Posner (1996), pp. 1700-1701 (discussing the negative externality argument).

${ }^{22}$ Cooter and Ulen (2012), p. 38.
} 
undermining value creation by private orders for its own members. These groups might involve wide-variety of players such as the bureaucrats that misuse their power for private gains and majority shareholders that manipulate resources in their corporation at the expense of the noncontrolling investors. When a private order is rotten, economic value is merely transferred from one to another group, rather than created. ${ }^{23}$ Thus, the powerful interest groups may prevent value creation as well as tunnel the private orders' wealth at the expense of all others, thereby harming the private order as a whole.

Because of the advantages and problems of private ordering, its impact on overall efficiency and welfare is unclear. The private ordering of industry associations, professional clubs, academic societies, and other member associations exemplify this controversy. By member associations we mean (1) private, formal, and self-governed entities; that are typically (2) non-commercial and nonprofit, and that (3) facilitate the provision of collective goods to their members. ${ }^{24}$ While many scholars have a positive stand on the overall effects of associations-notably 'social capital' literature argues that such associations are the source of effective democracy and social capital ${ }^{25}$; studies in organizational economics are optimistic as well $^{26}$ - there are also less optimistic findings. For example, Maria Larrain and Jens Prüfer explore whether the incentives of associations to lobby lawmakers has positive or negative effects on economy. They show that 'good lobbying'-influencing the political reform process to increase the level of property rights protection-and 'bad lobbying'-influencing rent-distribution to the detriment of nonmembers-are complements. This means that associations can exert valuable pressure on ineffective governments. On the other hand, however, these associations may also provide detrimental pressure on a legal system that functions well. ${ }^{27}$ Therefore, there is uncertainty about the impact of membership associations, and private orders in general, to overall efficiency and welfare. It is under this uncertainty that policy makers operate. They have to decide whether and how to promote, ignore, change, or prohibit altogether certain associations.

\footnotetext{
23 See generally Libecap (1989) (discussing the risk that powerful interest groups may block the emergence of utilitarian property rights arrangements).

${ }^{24}$ Schofer and Longhofer (2011), p. 542.

${ }^{25}$ Social capital is cooperative links between people such as common identity and friendship. See, for example Fukuyama supra note 18.

26 Tirole (1996).

27 Larrain and Prüfer (2015) (stressing that if property rights are better protected by the state than by private orders, associations have the capacities to bias laws and regulations as a result of lobbying, and to influence public opinion and policy outcomes).
}

\subsection{The limits of private ordering by member associations}

The state plays a key role when it comes to the emergence and evolution of membership associations. The ways in which states affect societies in general, and membership associations in particular, through their interventions, abstentions, and relationships with private orders has been in the centrum of attention for decades. Notably, Theda Skocpol in her project 'Bringing the State Back In' articulated two key perspectives on how the state affects private orders. $^{28}$ The first way-'Weberian'-focuses on the capacity of the state to influence private orders. Obviously, the state's capacity to cope with various problems is not static: it might increase, decrease, and even disappear. The second way-'Tocquevillian'-focuses on indirect influence of the state. From this perspective, "states matter not simply because of the goal-oriented activities of state officials. They matter because their organizational configurations, along with their overall patterns of activity, affect political culture; encourage some kinds of group formation and collective political actions [...]". ${ }^{29}$ The ways in which the state influences-both from the Weberian and the Tocquevillian perspectives-the emergence and evolution of membership associations is summarized in Table 1 below.

From the Weberian perspective, the state can authoritatively prohibit certain forms of private ordering and thus prevent their emergence. In many cases, however, private ordering springs-up from society. This is mainly because public orders are unable to provide order and effective regulation in every field. Indeed, the grassroots of membership associations can be found even in the world's most repressive countries - for example, the failure of the North Korean economy to prevent famine in 1990s necessitated illegal, but tolerated, entrepreneurial responses to secure food. $^{30}$ Therefore, even in states that are very hostile to private ordering, private ordering emerges due to the lack of capacity, or the willingness, of public orders to regulate in certain areas of societal life.

Moreover, public orders may actively work towards the expansion of member associations and initiate the emergence of new associations. For example, public orders nudge businesses, member associations, and other private actors to organize activities in areas in which public regulation has neither the ability nor the competence to

\footnotetext{
${ }^{28}$ Skocpol et al. (1986).

29 Ibid, p. 21.

${ }^{30}$ Consequently, a hybrid private/Party sector has been created not only as a survival strategy, but also to satisfy a wider range of needs. Noland (2016), pp. 234-245; See also Tudor and Pearson (2015), pp. 16-20.
} 
Table 1 Perspectives on the role of public orders in the emergence and evolution of member associations

\begin{tabular}{lc}
\hline Weberian State (goal-oriented) & Tocquevillian State (indirect influence) \\
\hline $\begin{array}{l}\text { The lack of capacity, or the willingness, of public orders to regulate in } \\
\text { certain areas leads to the emergence of private ordering }\end{array}$ & $\begin{array}{c}\text { Overall patterns of the activity of public orders indirectly influence } \\
\text { the emergence and evolution of private ordering }\end{array}$ \\
Public orders give associations incentives to expand the scope of their \\
activities
\end{tabular}

conduct a particular regulatory activity. ${ }^{31}$ Various forms of public-private co-regulation are yet another example of the complexity that stand behind the emergence and evolution of private ordering. ${ }^{32}$

Furthermore, the state influences the evolution of member associations by granting powerful regulatory privileges as well as by limiting the freedom of contract. Granting powerful privileges, on the one hand, could help establishing strong associations based on high contractual stability, while not granting the privileges, on the other hand, may prevent such an establishment. Consider state law constraints that many member associations-such as lawyer associations-face. Associations of lawyers, for example, are constrained by state laws to create rules that would prohibit lawyers to terminate their employment contracts with law firms without cause, before expiry and without paying compensation. ${ }^{33}$ These public constraints, for example, do not exist in the case of football regulation that-differently from lawyers-has evolved in a global system based on strong contractual stability. ${ }^{34}$

From the Tocquevillian perspective, the role of public orders in the emergence and evolution of member associations is indirect. Unlike the direct role of the public orders, however, the indirect role is largely unexplored. ${ }^{35}$ Scholars, for example, observe that the expansion of the modern state influence the emergence and evolution of membership associations. ${ }^{36}$ Consider US foreign anti-bribery enforcement that has resulted in rapid proliferation of anti-corruption interest groups during the last years. Expansive

\footnotetext{
$\overline{31}$ See Cafaggi and Iamiceli (2014) and Cafaggi (2012) (addressing transnational private regulation as an instrument to produce and protect global public goods).

32 See generally de Búrca et al. (2014).

33 Gomtsian (2017), p. 64.

${ }^{34}$ For the analysis of transnational self-regulation in professional services, see Delimatsis (2017) (arguing that we cannot yet see truly transnational private regulation in professional services, but that the foundations for such regulation are being built progressively).

35 Note that we see some of the prominent economic governance scholars recently advocating for the use of the 'Tocquevillian' approach in the studies of private ordering. See Ellickson (2016).

${ }^{36}$ Schofer and Longhofer (2011), pp. 544-546.
}

enforcement of state laws put the issue of international corruption on the agenda and set the basis of new anticorruption industry that generated multiple membership associations. $^{37}$

Furthermore, the emergence and evolution of modern member associations depends, to a large extend, on the openness of states to tolerate them. ${ }^{38}$ If state's overall pattern of activity is to discourage some forms of private ordering-being it because of negative externalities, associations' internal problems, or simply because of paternalism and restrictive state policies-many associations will not emerge and the existing ones will dissolve under state pressure. Consider, legal problems sharing economy firms, such as ridesharing and home-sharing platforms, have faced. Cities, states, and other public orders, in the name of public safety, health, and corporate social responsibility, have limited the freedom of action of these platforms and their users. ${ }^{39}$ Therefore, an association will emerge and sustain more likely in societies that tolerate them, for example, by ensuring broad freedom of contract. $^{40}$

Accordingly, the Weberian and Tocquevillian perspectives indicate that the emergence and evolution of modern member associations is influenced by complex publicprivate interactions. These interactions are shaped not only by goal-oriented public orders but also indirectly, by the overall patterns of activity of these orders. This shows that member associations usually face various direct and indirect constraints that public orders impose on them. Scholars investigating the emergence and evolution of good order should incorporate the composition of the said publicprivate interactions as well as the character of constraints provided by public orders into their research agendas. The following parts discuss how to do it.

\footnotetext{
37 See generally Rose-Ackerman (2011).

38 Schofer and Longhofer (2011).

39 Ranchordas (2015).

40 See Ellickson (2016), p. 250.
} 


\subsection{Illusion of purity-beyond purely private and purely public view}

Purely public and purely private modes of governance do not exist. In fact, sticking too much to traditional publicprivate divide could develop doubts about the ability of researchers to say something useful as far as the emergence and evolution of good order is concerned. In this context, a massive scholarly effort was devoted to the issue of jurisdiction, i.e., who-public order or private order-is more efficient. ${ }^{41}$ Naturally, states should intervene, and possibly disintegrate, private orders that deviate from universally agreed societal standards. Yet, in many cases government representatives face various trade-offs that may decrease the value of their potential involvement in particular regulatory area. Consider how the state commonly erects barriers to entry in industries such as the defense and aircraft industry to safeguard public health, environment, and safety. ${ }^{42}$ Moreover, the use of anti-trust laws to mitigate activities that make markets less competitive, clearly has trade-offs as it can block, for example, innovation and value-maximizing agreements among competitors. ${ }^{43}$

There is broad consensus that the state should set aside inefficient private norms. The economic governance scholars, however, urge that the state should intervene only if it has good information about such inefficiency. Otherwise, any state intervention is more likely to be redundant and weaken private orders by challenging the functioning of their established rules and other mechanisms. ${ }^{44}$ Therefore, a general rule of thumb for public orders is not to intervene in private orders if they are uncertain about their efficiency.

\footnotetext{
${ }^{41}$ Note that the key condition for successful functioning of some private orders is the legal system. Hence, the state also directly influences private ordering by forcing private entities to choose from different distributions of ownership forms. See Hansmann (2000) (arguing that the success of a particular form depends on the balance between the costs of contracting in the market and the costs of particular form).

42 In other industries such as energy and telecommunications, however, public orders are liberalizing historically foreclosed markets. See, for example, Competition Policy and an Internal Energy Market, Study of the European Parliament, July 2017. https://www. lse.ac.uk/collections/law/wps/WPS2016-08_Colomo.pdf. Accessed 23 Jan 2017

${ }^{43}$ For example, anti-competitive activities are a main feature of the EU's work that, through the European Commission and the Court of Justice of the European Union (CJEU), has defined a number of special responsibilities for large economic operators. Moreover, consider also bans on illegal agreements among competitors to refuse to deal with other competitors. See Richman (2009) (claiming that coordinated refusals among competitors may promote economic welfare)

${ }^{44}$ Katz (1996), p. 1752.
}

The advice about 'non-intervention' in private orders, however, applies only in some situations. In other words, the discussion about jurisdiction focuses only on one aspect of the relationship between public and private ordering. Most importantly, the discussion does not focus on the fact that the success of many private orders is associated with co-determination. This means that the various roles public orders play-from both the Weberian and Tocquevillian perspectives - in the emergence and evolution of private orders are missing from the discussion. ${ }^{45}$ To advance discussions on the emergence of good order, we provide a model of how private orders evolve under constraints provided by public orders.

\section{The model of interventions-public orders and membership associations}

Game-changing events that lead to financial success, political revolutions, or innovation, do not come "out of the blue"; they are supported by institutions. However, the formation of "right institutions", particularly in a globalized world, is a mystery. This mystery often depends on the context in which institutions function. For example, private orders such as mafia might be inferior to the centralized provision of reliable institutions by states, but in the absence of state action, even such substandard alternatives create economic value. ${ }^{46}$ Exclusive supply of institutions by the state may lead to similar outcome. Consider, for instance, public orders based on the exclusion of civil society and the lack of accountability of institutions. ${ }^{47}$ Although it is likely that such centralized public orders may forgo the efficiency gains of private ordering by completely denying any private ordering, they may create economic value in cases in which no better alternative can ensure basic public goods. These orders are better than a state of civil war accompanied by chaos, torture, and death, as can be witnessed in a number of contemporary conflicts. ${ }^{48}$ The described orders, however, are far from ideal, and societies need to be looking for alternatives that are more efficient. We see such alternative in the existence of constrained private orders.

\footnotetext{
45 See the discussion in Sect. 2.2 above.

46 See McMillan and Woodruff (2000).

47 Acemoglu and Robinson (2016). Paths to Inclusive Political Institutions, p. 3. http://scholar-harris.uchicago.edu/sites/default/files/ jamesrobinson/files/path_to_inclusive_political_institutions.pdf. 23 Jans 2017.

${ }^{48}$ See, for example, Human Rights Watch. Syria. https://www.hrw. org/middle-east/n-africa/syria. 23 January 2017.
} 


\subsection{The importance of private orders being constrained}

Our central premise is that the success of modern private orders is closely associated with the constraints imposed by public orders. The fact that member associations are, at least to some extent, constrained private orders represents an opportunity that the two failures of private orderingnegative externalities and internal imbalances-will be reduced to the minimum. At the same time, being a constrained private order that does not need-and does not face-public interventions, means that the advantages of private ordering can be used to the fullest and benefit both private ordering and society as whole.

Our premise about the importance of constrained private orders is based on the assumption that many current societies struggle to produce welfare particularly because elitist groups, which have a natural tendency to use the order for promoting self-gain, lead them. The elites use such order "to limit economic entry to create rents, and then using the rents to stabilize the political system and limit violence". 49 In other words, these orders are tools of the powerful to remain in the lead. To remain in control, the elitist groups create, and often legitimize, institutions that disproportionally disadvantage other groups. Moreover, such orders are very likely inefficient because the said limitations of economic entry result in a system in which economic value is merely transferred from one to another group instead of being created. ${ }^{50}$ Therefore, elitists have not only the tendency to undermine the creation of institutions ensuring equal distribution, but also the creation of economic value. The result is a sub-optimal private order.

In this context, the success of modern society is closely associated with constraints that are imposed on the existing power structures. For example, Daron Acemoglu and James Robinson see these constraints in the existence of 'inclusive institutions'. They argue that the societal economic success is dependent on the emergence of 'inclusive political institutions', characterized by pluralism and political centralization, and 'inclusive economic institutions', characterized by law and order, and relatively secured property rights. ${ }^{51}$ This type of institutions allows the transition between orders based on the rent-creation by

\footnotetext{
49 North et al. (2006) A conceptual framework for interpreting recorded human history, New York: Cambridge University Press. Working Paper 12795, p. 2. http://www.nber.org/papers/w12795. Accessed 23 Jan 2017; See also North et al. (2009).

50 See Libecap (1989) and comment in supra note 23.

51 Acemoglu and Robinson (2012), pp. 81-82. For example, in Ancient Athens and Early Modern England, inclusive political institutions emerged "from a balanced increase in state capacity and the distribution of power". Acemoglu and Robinson supra note 47 .
}

elitist groups and those based on open and competitive environment. $^{52}$ Certainly, the established power groups oppose inclusive political and economic institutions because these institutions, effective in creating value though they may be, threaten the position of elites. They may lose their monopolies in both political and economic life. The answer to the question why some states have exclusive and others inclusive institutions is then in the ability of civil society to impose checks on the existing elites, thereby constraining their ability to maintain the established equilibrium. ${ }^{53}$ Therefore, institutions that constrain orders created by elitist groups are extremely important for modern societal development.

While the above-discussed theories generally apply to the successful functioning of public orders, we propose extending them to the successful functioning of private orders. The emergence of inclusive institutions requires constraining private orders to limit the excessive power of elitist groups. If such constraints are available, and the private order is able to avoid excessive external interventions by public orders, it is reasonable to assume that such constrained private orders are likely to limit the failures of private ordering. This is because extreme deviations from fundamental rules and norms supported by a relevant public order would provoke the very thing private orders tried to avoid-external interventions into their domain. In other words, when a membership association ignores the problem of negative externalities or becomes heavily unbalanced by abusing the position of weak constituencies, it is, in fact, inviting the state to intervene, thereby undermining its own authority. Therefore, if membership associations are constrained, and meanwhile are able to refrain from excessive external interventions, they are more likely to create a private order based on inclusive institutions than if they are not constrained. Being constrained may be the best outcome for any membership associations.

\subsection{Advancing the discussion: the state in the role of civil society}

The role of public orders in the evolution of successful private orders is to ensure that private orders have the freedom to utilize their advantages and, at the same time, ensure that negative consequences of private ordering are not dominant. We can draw parallels with the case of nation states in which the key role in limiting excessive powers of elites belongs to the civil society. ${ }^{54}$ In the case of private orders, the state is 'civil society'. Moreover,

\footnotetext{
$\overline{52}$ See generally North supra note 49.

53 Acemoglu, Robinson. State building: a political economy perspective (forthcoming in 2018).

54 Ibid; Acemoglu and Robinson supra note 47, pp. 2-3, 5-15.
} 
policing elites in monopolistic private orders is even a more complicated and urgent task because there is often no direct representation of constituencies inside the order. As a result, the elites of a private order are more likely to become detached from the constituencies whose interests they are supposed to look after. Public orders then assume the role of 'civil society' in interacting with private orders. This requires public orders to play two interconnected, but different, roles. The first role is authoritative, as it includes the capacity to change, limit, or even prohibit certain functions of private orders. The second role is indirect, as it requires public orders to influence private ordering while respecting their rules and ways they want to operate. The model of public interventions is illustrated in the chart below (Fig. 1).

In their first role, public orders may have capacity to intervene authoritatively in private orders. The higher negative externalities and internal imbalances are, the more concern a public order interested in efficiency will show for mitigating the said failures of private ordering. In these occasions, however, public orders should follow the advice provided by the economic governance scholarship and intervene only if they have good information about inefficiencies of private ordering. Public orders should challenge private orders in case of negative externalities and other failures, particularly to limit the potential of powerful interest groups that are emerging inside private orders to promote their self-interest, thereby completely changing the legitimate nature of these orders. ${ }^{55}$ By challenging, we mean authoritative interventions such as overruling a decision of member associations to, for example, include certain interest groups in decision-making processes within the associations. Naturally, the effectiveness of such interventions also depends on the capacity of public orders to do so.

Importantly, stronger power of a public order does not, and certainly should not mean more intensive and frequent external interventions in private orders. History suggests that if the state does not tolerate private ordering, then the state's interventions are directed towards replacing successful private orders, rather than strengthening them. ${ }^{56}$ If public interventions, for example, replace private ordering

\footnotetext{
55 Note that while private ordering sometimes emerges beyond the reach of the state-for example as a consequence of weak state institutions-private orders in some way impinge on the state's jurisdiction and their ability to govern a given field is limited by the sovereign power of states which can reclaim, more successfully or less successfully, the authority.

56 Masten and Prüfer (2014). The discussed advantages of private ordering are closely related with the notion of civil society. Civil society is a precondition of modern social development that plays the key role in the transition between orders based on the rent-creation and open access orders based on free competition. See generally North supra note 49.
}

by unstable contractual relations, costlier dispute resolution and enforcement mechanisms, and red tape, economic value will be lost. Therefore, reclaiming the power to assist and improve private orders should be a matter of scale.

Hence, stronger power of a public order rather means, and should mean, that the state accepts the role in which it can be replaced, perhaps temporarily, by a private order. Accordingly, the co-evolution of powerful private and public orders implies strategic external interventions that correct the failures of private ordering, but do not meddle into the internal affairs of the private order too much. In other words, the public-private interactions direct the evolution of private orders by setting a starting benchmark of freedom, but then stepping back and letting private ordering function within such benchmark.

This, however, does not prevent public orders from influencing private orders, even if they function within the said benchmark. In their second role, hence, public orders should be acting, as an equal partner to private orders, for example when co-determining the substance of institutions in a regulatory space that the state shares with private orders. ${ }^{57}$ From this perspective, some of state interventions may be similar to a democratic process in which the civil society influences public decision-making. Public orders may protect private orders in the same manner as the civil society protects the state capture by powerful interest groups. ${ }^{58}$ It must be noted, however, that even if the state acts as an equal partner to private orders, it still may seek to prefer its own interests rather than private-order's interests. For example, it may use lobbing, or negotiate with, private orders with a view to change their rules in a way that benefit the public order. Nevertheless, as long as public orders recognize the advantages of private ordering and use such strategies carefully, their self-interest cannot destabilize the entire systems of private orders. To the contrary, overall, these interactions can strengthen private orders, rather than weaken them because they limit power disbalances inside private orders. The public-private interactions

\footnotetext{
57 Switzerland is an example of a public order that recognizes the benefits of private orders and intervenes only in the most wanting cases. See, for example, Duval (2015), pp. 246-247. Another example is the EU that has always expressed great respect for autonomy and self-regulation in sports. However, this comes with a condition: the EU Commission makes it clear that good governance and respect for EU law is a condition for the self-regulation and autonomy of sports. See EU Commission, Communication "Developing the European Dimension in Sport" (Jan 2011). Cf. Meier and Garcia (2015), p. 893 (arguing that FIFA has a market power to impose its will on national governments).

58 Hellman et al. 2000. "Seize the State, Seize the Day". State Capture, Corruption, and Influence in Transition. Policy Research Working Paper, The World Bank Institute. http://siteresources. worldbank.org/INTWBIGOVANTCOR/Resources/seize_synth.pdf. Accessed 23 Jan 2018.
} 


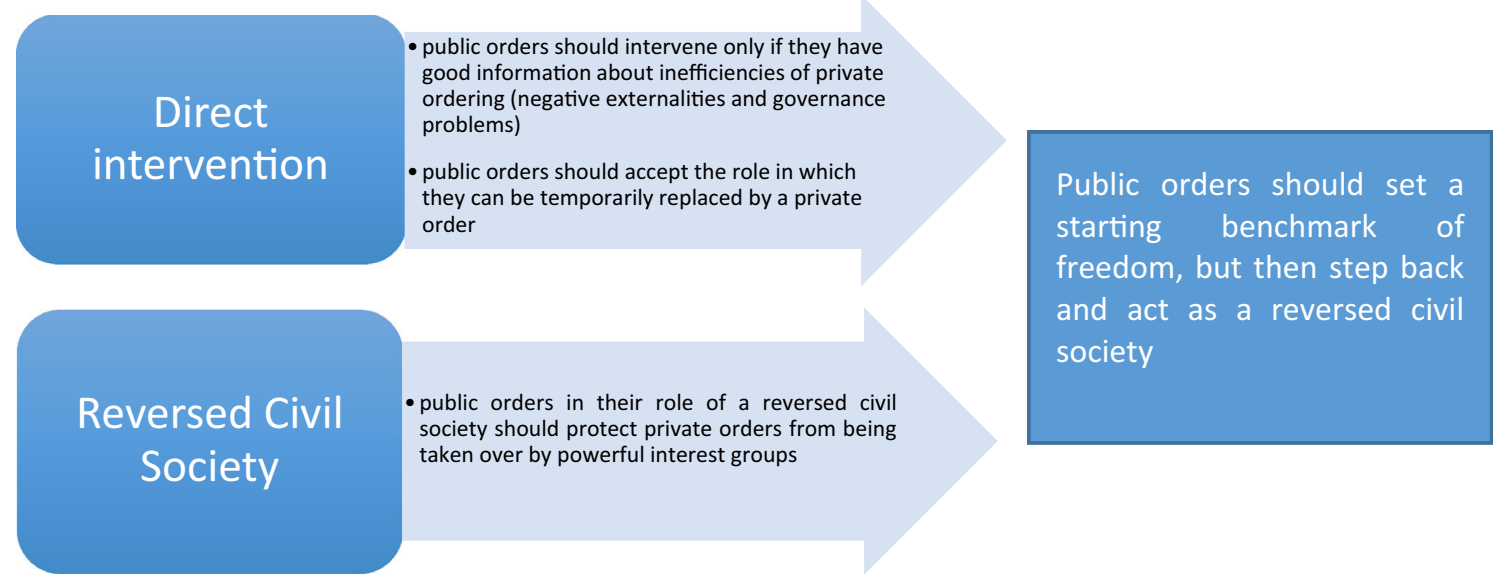

Fig. 1 The model of interventions

involving the private order of FIFA are the example of this dynamics.

\section{Case study: FIFA's private order}

FIFA is an association that not only promotes the game of football, organizes international football tournaments, but it is also an economic operator. Powerful sponsors support FIFA; it negotiates billions of dollars in annual revenues through sales of media and marketing rights, and receives massive tax exemptions in a number of countries. ${ }^{59}$ Alongside its commercial success, FIFA has come under intense criticism for its controversial practices, including corruption, money laundering, and its support and supervision of sporting events that are connected with the violations of fundamental rights. ${ }^{60} \mathrm{It}$ is, however, important to distinguish failures in FIFA's management and administration from its advances in building and maintaining global legal order that materialized many of the advantages of private ordering. Keeping these advantages while limiting negative externalities, corruption, and other undesirable practices is the key problem that FIFA and public orders face.

\subsection{FIFA as a global regulator}

FIFA is a powerful regulator. FIFA's legal order goes way beyond playing rules and coordination of the timetables. ${ }^{61}$

\footnotetext{
59 FIFA Financial Report 2016. https://resources.fifa.com/mm/docu ment/affederation/footballgovernance/02/87/89/44/fr2016digitalen_ neutral.pdf. Accessed 23 Jan 2018; Mitra (2015), pp. 7-8 (analyzing FIFA's tax exemption during the 2014 World Cup in Brazil).

${ }^{60}$ See, for example, Pielke 2013.

${ }^{61}$ See FIFA, Laws of the game 2015/2016. http://resources.fifa.com/ $\mathrm{mm} /$ document/footballdevelopment/refereeing/02/36/01/11/lawsofthe gameweben_neutral.pdf. Accessed 23 Jan 2018.
}

For example, football clubs have to comply with various professional, integrity, and financial rules to secure a license to participate in international and, as a rule, topdivision national competitions. ${ }^{62}$ Furthermore, employment matters cover relations between the clubs and their primary employees-professional athletes-and relations among different clubs with regard to soliciting professional athletes from each other. ${ }^{63}$

With the purpose of protecting its monopoly, FIFA has developed a complex organizational structure, including its member associations, in most of the cases each representing one independent country, and six confederations. ${ }^{64}$ Furthermore, FIFA has also private dispute resolution venues and sophisticated system of sanctions and incentives promoting compliance with the decisions of the private order's dispute resolution bodies. ${ }^{65}$ Particularly, FIFA recognizes the mandatory jurisdiction of the Court of Arbitration for Sport (CAS) to decide on disputes between FIFA, its members, confederations, leagues, clubs, players, intermediaries, and other involved parties. ${ }^{66}$ This complex mechanism ensures compliance with FIFA's global order.

\footnotetext{
62 See Article 2291 and 4311 of FIFA Regulations: club licensing, 2007. http://resources.fifa.com/mm/document/affederation/administra tion/67/17/66/club_licensing_regulations_en_47341.pdf. Accessed 23 Jan 2018.

${ }^{63}$ See FIFA Regulations on the status and transfer of players, 2015. https://resources.fifa.com/mm/document/affederation/administration/ 02/70/95/52/regulationsonthestatusandtransferofplayersjune2016_e_ neutral.pdf. Accessed 23 Jan 2018 (hereinafter Transfer Regulations). ${ }^{64}$ FIFA is an umbrella organization consisting of 211 national associations operating within six continental confederations.

${ }^{65}$ For a detailed discussion of FIFA's private legal order and the system of rules and incentives that promote compliance with the order, see Gomtsian (2017).

${ }^{66}$ See Article 66 of FIFA Statutes. FIFA Statutes: Regulations Governing the Application of the Statutes Standing Orders of the Congress, April 2015. http://www.fifa.com/mm/document/affedera tion/generic/02/58/14/48/2015fifastatutesen_neutral.pdf. Accessed 23 Jan 2018.
} 
FIFA obliges its confederations to ensure that international football competitions with the participation of the clubs from national associations are not be organized without the consent of the affected confederation and the approval of FIFA. ${ }^{67}$ Such consent is de facto conditional upon compliance with FIFA's rules, including an obligation to comply with the decisions of FIFA and the CAS. In this way, FIFA effectively regulates every party that participates in organized football competitions, including players, clubs, coaches, managers, club investors, officials, sponsors, and spectators.

\subsection{Direct intervention of the EU into FIFA}

To be fair, not all the credit behind the expansion of FIFA's private order goes to FIFA alone. Public orders, such as the sovereign jurisdictions of FIFA's member associations and supra-national organizations like the EU, influence the evolution of the order. ${ }^{68}$ This influence is the result of strong tensions between FIFA's regulatory autonomy and the sovereign power of public orders. The contradictions are especially visible in matters related to equality and/or nondiscrimination of workers, the treatment and qualification of minors, the freedom to choose employment, and the freedom of movement. For example, the inability of players to terminate their contracts without cause, before expiry and without paying compensation, is in stark contrast with traditional employment laws, according to which employees are free to end employment without cause by prior notice. ${ }^{69}$

The rise of FIFA was, at the first stage, made possible by the reluctance of states and supra-national organizations such as the EU, to intervene in the governance of football. FIFA is an international private association established in Switzerland, a country where local authorities and courts have always been reluctant to intervene into the internal affairs of private associations. In addition, sports in general and football in particular have always received special treatment, which prevented too much state involvement. ${ }^{70}$ In effect, FIFA, as most member associations would naturally try to do, filled regulatory gaps by designing specific regulations. In other words, the lack of attention of public orders to provide effective institutions resulted in a self-regulation of football actors.

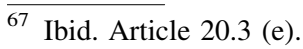

${ }^{68}$ See, for example, Transfer Regulations supra note 63. See generally (Weatherill 2017; Mataija 2016; Duval and Van Rompuy 2016).

69 Articles $13-15$ of the Transfer Regulation provide that "a contract between a professional and a club may only be terminated upon (1) expiry of the term of the contract or by a mutual agreement (Article 13), (2) based on just cause (Article 14), or (3) by the player who has, in the course of the season, appeared in less than $10 \%$ of the official matches of his/her club (Article 15).

${ }^{70}$ See generally Szyszczak (2007), p. 3 et seq.
}

With the commercialization of football and the increasing influence of FIFA's private order, however, public orders, and mainly the EU have become more active. At this stage, the EU authoritatively defined the acceptable benchmark of FIFA's activities, at least when the EU law and FIFA's transfer system is concerned. The groundbreaking case here is the Bosman ruling of the CJEU. ${ }^{71}$ Prior to this decision, football players were tied to their clubs indefinitely and could move between clubs only after the payment of compensation. When the employment contract of Jean-Marc Bosman in his Belgian club expired, he intended to move and play for a French football club. The latter, however, was not willing to pay the transfer fee and, as a result, the Belgian football authorities did not transfer the player's certificate, rendering Mr. Bosman ineligible for playing in France. Mr. Bosman took the matter to court and the CJEU declared the rule incompatible with the freedom of movement for workers and competition law. ${ }^{72}$ This decision set a starting benchmark of the freedom of private order to self-regulate, leading to the reshaping process of transfer rules into FIFA's order we know today. After Bosman, the EU and states stepped back and allowed FIFA self-regulate within the constraints imposed by public orders. We illustrate these developments in the following sections.

\subsection{The EU in the role of a reversed civil society}

Bosman was, until the FIFA-gate scandal, ${ }^{73}$ the only major authoritative intervention of a public order into the FIFA's affairs. The implication of the CJEU's decision was that the old system was not effective anymore, but neither the EU, nor European countries took the initiative to design new transfer rules. Public orders, based on the idea of the autonomy of sports, let FIFA and UEFA, the governing body of European football, to draft new transfer rules that would meet the needs of football-related actors and at the same time would satisfy the requirements of the laws of public orders. In other words, the European Commission did not impose minimum requirements that had to be complied with by FIFA in the process of designing new transfer rules. The European Commission, instead, recognized the advantages of private ordering in this field and preferred to preserve the private order's autonomy. ${ }^{74}$

\footnotetext{
$\overline{71}$ Case C-415/93, URBSFA v. Bosman et al., EU:C:1995:463.

72 See Ibid.

${ }^{73}$ See Sect. 4.4 below.

${ }^{74}$ Our argument fits into the ongoing discussion about this privatepublic interaction in football and beyond, most importantly see Weatherill (2017) (discussing, among others, a sporting margin of appreciation and its limits); Mataija (2016) (underlying the tension between sporting bodies and public orders); Duval and Van Rompuy (2016) (suggesting that Bosman should be interpreted as the imposition of a democratic check on the exercise of private power in football and beyond).
} 
The European Commission's role in drafting post-Bosman transfer rules is one of the forms how public orders can act in the role of civil society in the context of private ordering. The content of transfer rules is a product of negotiations between the European Commission, FIFA, UEFA, and FIFPro, the latter a global trade union representing the interests of professional football players. The Commission's role in these negotiations was to ensure the inclusion of the EU policy rationales into employment rules in football. The result is a new system that aims to promote contractual stability between players and clubs while respecting each player's right to free movement. ${ }^{75}$ To achieve this aim, the concept of contractual stability has been introduced into player transfer rules to replace the pre-Bosman system of transfer fees. ${ }^{76}$ Accordingly, transfer fees due after the expiry of a contract have been substituted with a compensation due for the unilateral termination of a valid contract without just cause.

Such non-direct-interventions by public orders have also been the highlight of negotiations about subsequent modification of FIFA's order. While the EU have means to block amendments of FIFA's private order, it does not intervene directly. Even if such amendments of FIFA's order may come close to violating EU's freedoms and competition laws, the CJEU and other EU institutions refuse to intervene if the changes meet certain minimum requirements. The first case study below that focuses on socalled "third-party ownership" illustrates this. The second study, related to financial integrity in football, highlights how constant interactions between FIFA and public orders influence the final form of the amendments in the rules of FIFA's private order. The final nature, content, and application of amended rules are, rather, the result of a dialogue taking part between the football stakeholders and the EU Commission. This rising procedural approach is in detail illustrated in our third example.

\footnotetext{
75 Czarnota (2013), pp. 3-5, 7. To be fair, the subsequent interpretation of the principle of contractual stability by FIFA's internal dispute resolution bodies and the CAS seem to have been gradually giving priority to contractual stability over free movement. Ibid, pp. 37-38. In its later cases, the CAS considers it more appropriate to apply the "positive interest" approach that aims to put the injured party in the position it would have been if no contractual breach had occurred. Undoubtedly, the positive interest approach has a stronger effect on discouraging player mobility than the residual value approach. See also de Wagen (2011), pp. 42-56.

76 See CAS 2008/A/1519, FC Shakhtar Donetsk v. Matuzalem Francelino da Silva \& Real Zaragoza SAD \& FIFA, Award 19 May 2009; CAS 2008/A/1520, Matuzalem Francelino da Silva \& Real Zaragoza SAD v. FC Shakhtar Donetsk \& FIFA, Award 19 May 2009.
}

\subsubsection{Third party ownership}

The first example dates back to December 2014 when FIFA updated player transfer rules to ban so-called "third-party ownership" of football players. ${ }^{77}$ According to the newly introduced Article 18ter of FIFA's Regulations on the Status and Transfer of Players, clubs and players are banned from entering into an agreement with a third party which gives the third party any right or interest in relation to the future transfer of the player to another club. ${ }^{78} \mathrm{~A}$ third party is a party other than the two clubs transferring a player from one to other, or any previous club with which the player has been registered. ${ }^{79}$

Third-party ownership, which became increasingly popular in late 2000 s, allows a third-party private investor to acquire interest in the future transfer value of the player, commonly known as a player's economic rights. ${ }^{80}$ As a result, when a player transfers to another club before the end of the player's employment contract with his/her current club for a transfer fee, the third-party investor is entitled to a portion of the transfer compensation in proportion to the third-party owner's share of the economic rights of the player. The third-party owner can thus earn a return on its earlier investments if the player's transfer fee is higher than the valuation at the time the third party made the investment; the selling club, in its turn, can use the money from the third-party owner to sign and develop players it could not afford otherwise. Some football associations banned third-party ownership of footballers earlier. Particularly, the governing bodies of football in England outlawed this practice in 2008 following the transfers of two Argentinian players, Carlos Tevez and Javier Mascherano, to West Ham United Football Club. ${ }^{81} \mathrm{~A}$ London-based investment fund partially owned the economic rights of both players in an arrangement that allowed the third-party owner to influence player transfer decisions and the transfer compensation. ${ }^{82}$ This created potential conflicts of interests and the English football authorities imposed an absolute ban on third-party player ownership from the beginning of the 2008-2009 season. ${ }^{83}$

Notwithstanding problems associated with third-party ownership of players' economic rights, not all in the world

\footnotetext{
77 FIFA, Circular no. 1464, December 2014. https://www.fifa.com/ $\mathrm{mm} /$ document/affederation/administration/02/49/57/42/tpocircular1464_ en_neutral.pdf. Accessed 12 Jan 2018.

78 Transfer Regulations supra note 63, Article18ter (1).

79 Ibid, Definition 14.

${ }^{80}$ Geey (2016).

${ }^{81}$ Williams (2009); Wilson, September 2016. Football's Third-Party Ownership Rule Explained. BBC News. www.bbc.co.uk/news/ business-37483203. Accessed 12 Jan 2018.

82 Williams (2009), pp. 92-93; Wilson supra note 81 .

${ }^{83}$ Geey (2016), pp. 245-46.
} 
of football welcomed the ban imposed by FIFA. In particular, many in South American countries, Spain, and Portugal, where the practice of third-party ownership was widespread, opposed the ban arguing that many local clubs could not compete on an international level without the backing of external investors. ${ }^{84}$ Critics often referred to the example of Club Atlético de Madrid, a club from Madrid associated with the working class population of the city, which relied on third-party ownership to sign star players. Player agents partially financed these deals in arrangements under which the agents owned stakes in the economic rights of players. ${ }^{85}$ If the player transferred, the agent shared in the profits. This allowed Atléti to sign top players, like Radamel Falcao, and compete both with the powerhouses of the Spanish football-Real Madrid Club de Fútbol and Futbol Club Barcelona-and internationally. ${ }^{86}$

In February 2015, the Spanish and Portuguese professional football leagues filed complaints on FIFA's ban of third-party ownership with the European Commission. ${ }^{87}$ The complaint argued that the ban violated the EU's competition laws and the fundamental rights to free movement of capital and labor. ${ }^{88}$ In turn, UEFA and FIFPro lodged a complaint with the European Commission questioning the legality of third-party player ownership under the EU law and asking the European Commission to endorse FIFA's ban of thirdparty ownership. ${ }^{89}$ The major concern of UEFA and FIFPro was the ability of third-party owners to control or influence the transfer activity of players who were the subject of a third-party ownership arrangement. ${ }^{90}$ The economic interests of external investors could influence transfer decisions at the expense of the sporting interests of players and clubs. This would not only cause players to change employment frequently, sometimes at the risk of not adapting in the new club, but might also hurt clubs as they needed to fill the gaps left by the departing players. ${ }^{91}$ Moreover, since third-party

\footnotetext{
${ }_{84}$ Lindholm (2016), p. 138, La Liga (2016), pp. 236-237, Reck (2016), p. 244.

${ }^{85}$ Simon Kuper, Inside Atlético Madrid, Financial Times, November 14,2015 , at 17-18.

${ }^{86}$ Id. See also La Liga (n 96), at 237.

87 European Parliament, January 2016. Briefing: "Third-Party Ownership" of Football Players. http://www.europarl.europa.eu/RegData/ etudes/ATAG/2016/573940/EPRS_ATA(2016)573940_EN.pdf.

Accessed 12 Jan 2018.

88 Ibid.

${ }^{89}$ UEFA, April 2015. UEFA and FIFPro Launch Complaint Against Third-Party Ownership. http://www.uefa.com/insideuefa/stake holders/players-unions/news/newsid=2230203.html?redirectFromOrg= true\#/. Accessed 12 Jan 2018.

90 Ibid.

91 Poli (2016) (reporting complaints of a footballer who had to transfer six times in 7 years after a third-party acquired controlling interest in the player's economic rights).
}

player ownership arrangements typically require the club to buy out the external investor if the player is not transferred or is transferred at a low fee, third-party player ownership resembles risky borrowing and may threaten club insolvency if the player is not successful. ${ }^{92}$

Despite strong arguments that FIFA's third-party player ownership ban violated EU's freedoms and competition laws, ${ }^{93}$ the European Commission, upheld the prohibition by deciding not to initiate formal proceedings. ${ }^{94}$ According to the Commission, potential conflicts of interests between clubs, players, and investors resulting from third-party ownership of players justify the proportionality of the absolute ban. ${ }^{95}$ As a result, the Commission demonstrated its willingness to recognize the needs in football and allowed a highly contestable rule to stand.

This case, however, does not imply that FIFA is free to ignore the rules of public orders. FIFA and public orders are in constant interaction-be it via direct talks and negotiations or through litigation of football-related matters in state courts-which test and set the boundaries of autonomy and self-regulation in football. In effect, despite the fact that public orders usually tolerate regulatory changes of FIFA's order, FIFA reflects the aims of public orders, thereby ensuring more internal balances between football stakeholders. UEFA's Financial Fair Play rules, presented in the following section, are a revealing example of this dynamics.

\subsubsection{Financial fair play}

Football generates billions in revenues. Large portion of the money goes through professional clubs that invest them to improve their competitiveness on the pitch. The

\footnotetext{
92 Duval A, Maren O, December 2015. Unpacking Doyen's TPO Deals: FC Twente's Game of Maltese Roulette. Asser International Sports Law Blog. http://www.asser.nl/SportsLaw/Blog/post/unpack ing-doyen-s-tpo-deals-fc-twente-s-game-of-maltese-roulette-by-antoineduval-and-oskar-van-maren. Accessed 12 Jan 2018.

93 See Lindholm (2016), pp. 140-43; La Liga (2016), p. 238. According to a report published by the Spanish Competition Authority, the prohibition of third-party player ownership violates both national and EU laws. La Liga (2016), p. 238.

${ }^{94}$ ESPN, October 2017. European Commission Upholds Third-Party Ownership Ban. http://www.espn.co.uk/football/blog-fifa/story/ 3228435/european-commission-upholds-third-party-ownership-ban. Accessed 12 Jan 2018.

95 Ibid. Recent reports, however, suggest that third-party player ownership practices are making a comeback in a new form. Particularly, external investors use "intermediary" football clubs to sign players that in fact have never played or trained with the club. Although the player represents another club, when the player is transferred, the intermediary club receives all or part of the transfer fee. Apollon Limassol, a Cypriot football club, was allegedly involved in signing players from Serbia or Romania who stayed to play for their cash-strapped home clubs. Apollon acted as a thirdparty buyer by purchasing economic rights of players and profiting from their subsequent transfers to stronger leagues.
} 
spending of football clubs has spiraled in recent years. In summer 2017, European transfer spending reached a record high of $€ 5.6$ billion, which was $€ 1.6$ billion (40\%) more than in the previous summer transfer window. ${ }^{96}$ For example, while Premier League clubs spent a combined $£ 630$ million in the 2013 summer transfer window, it was already $£ 1.41$ billion in the 2017 summer transfer window. ${ }^{97}$ The problem is that only small elite of clubs and owners centered in Europe's top leagues are profitable. ${ }^{98}$ Beyond the elite are thousands of clubs and their players that struggle. This creates a pyramid in which a vast majority of clubs and governing bodies are at "medium to high risk' of financial failure." 99 To address these concerns, UEFA introduced new regulations that are in stark contrast to what is generally acceptable under the EU competition law.

In business, predominantly the market ensures rational financing of economic operators. Under the danger of going bankrupt, for example, businesses are generally allowed to spend in some years more than they earned in previous years. In football, however, the public orders gave UEFA freedom to intervene into the market by limiting such spending by the so-called Financial Fair Play Regulations (FFP). ${ }^{100}$ The core of the FFP is the break-even requirement. ${ }^{101}$ With certain exceptions, this requirement generally provides that clubs cannot have expenses that are higher than their previous year's revenues. The aim of the FFP is, among others, to ensure that clubs settle their liabilities and to encourage responsible spending for the longterm benefit of football. ${ }^{102}$

\footnotetext{
96 UEFA 2017. The European Club Footballing Landscape, pp. 36-37, https://uefa.app.box.com/v/benchmarking. Accessed 26 Jan 2018.

97 The Telegraph, September 2015. Premier League transfer window: Record breaking year as spending reaches £lbillion. http://www. telegraph.co.uk/sport/football/competitions/premier-league/11837405/ Premier-League-transfer-window-Record-breaking-year-as-spendingreaches-1billion.html. Accessed 26 Jan 2018. Goal, September 2017. Premier League Clubs Shatter Transfer Record with $£ 1.4$ billion spending. http://www.goal.com/en-gb/news/premier-league-clubsshatter-transfer-records-with-14/nm8q7go476471vibc1ti714tq. Accessed 26 Jan 2018.

98 In the 2017 summer transfer window, English, Italian, French, Spanish, and German leagues accounted for $80 \%$ of spending. UEFA 2017 supra note 96 , p. 37.

99 Andrews and Harrington (2016) Off pitch: football's financial integrity weaknesses, and how to strengthen them. faculty research working paper series, p. 2. https://research.hks.harvard.edu/publica tions/getFile.aspx?Id=1309. Accessed 26 Jan 2018.

100 UEFA, UEFA Club Licensing and Financial Fair Play Regulations, https://www.uefa.com/MultimediaFiles/Download/Tech/ uefaorg/General/02/26/77/91/2267791_DOWNLOAD.pdf. Accessed 26 Jan 2018.

101 Articles 58-64 of the FFP.

102 Article 2(2) of the FFP.
}

While, the regulations have allegedly decreased club's investments during transfer windows as well as player's wages, there is a strong agreement among scholars that the FFP violates the EU competition rules. Scholars argue that the break-even requirement is a horizontal agreement between clubs—crisis cartel—that limits investments. ${ }^{103}$ Such cartel is prohibited under Article 101(1)(b) of the Treaty on the Functioning of the European Union (TFEU) and the CJEU has repeatedly held that such measures constitute a restriction of competition by "object". ${ }^{104}$ Despite a number of legal challenges in courts, however, the FFP has survived.

The current content of these rules is the result of a complex process of negotiations. During these negotiations, many alternative solutions to the break-even rule were possible. The so-called hard salary caps and bank guarantees would likely be options that are more balanced than current rules. ${ }^{105}$ Nevertheless, at the end of the day, the threat of elite clubs to separate from UEFA to establish their own league outside FIFA's private order was a powerful argument. ${ }^{106}$ In effect, while the initial idea of limiting external funding might not have been well received by public orders, the centrum of these negotiations was inside the world of football that determined its content. The break-even rule-justified by the need to improve financial integrity of clubs-favors large clubs and top players. Their cartelization and rent-shifting, to the detriment of all others, offset losses related to the decreasing amounts of external funding for signing new players and other activities. ${ }^{107}$

While the creation of the cartel may indicate that the nondirect-intervention of the EU, in fact, did not contribute to a balance between various interest groups in football governance, two crucial issues should not be underestimated. First, indeed, the break-even rule, on the one hand, undermines many aspects of the EU competition policy. One the other hand, however, it clearly supports the aims and objectives of the EU policy in the field of State aid. ${ }^{108}$ Unlike businesses in serious financial

\footnotetext{
103 Serby (2016). Weatherill, May 2013. The legal ambiguous status of 'Financial Fair Play'. Soccernomics. http://www.soccernomicsagency.com/?p=469. Accessed 26 Jan 2018; Petit (2014) 'Financial Fair Play' or 'Oligopoleague' of Football Clubs?. A Preliminary Review Under European Union Competition. https://papers.ssrn.com/ sol3/papers.cfm?abstract_id=2450719. Accessed 26 Jan 2018.

104 Consolidated Version of the Treaty on the Functioning of the European Union, art. 45, May 9, 2008, 2012 O.J. (C 326). See C-209/07, Competition Authority v Beef Industry Development Society Ltd et Barry Brothers Meat Lt., 20 November 2008, Rec. 2008 p. I-08637, §21. 105 Serby (2016), pp. 44-45.

106 Ibid.

107 Ibid, pp. 44-45.

108 Joint Statement by Vice-President Joaquin Almunia and President Michel Platini, March 2012, para 7. http://ec.europa.eu/competition/ sectors/sports/joint_statement_en.pdf. Accessed 26 Jan 2018 (the European Commission supported the FFP by issuing a joint statement of the European Commission and UEFA about the desirability of the FFP).
} 
difficulties, football clubs go rarely bankrupt, mainly because of unauthorized public interventions. In this way, the actions of the EU Commission are strongly motivated by the systemic failure to address unlawful State aid in professional football that makes FIFA's order rotten from inside ${ }^{109}$ From this perspective, public orders once again left the tough decision-whether to support regulations that may lead to a cartel based on competition between financially independent clubs or whether to ignore high risk of unlawful State aid - to the private order.

Second, indirect activities of the reversed civil society and various football stakeholders have modified the functioning of FFP. This group includes not only the EU Commission, which actively promoted its State aid policy, and the CJEU, which has not intervened directly into FFP, but also others that have challenged FFP in front of national and European institutions. Consequently, the application of FFP is not as strict as it could be. Most importantly, "the nature and content of the rules has gradually shifted towards a more liberal approach to external investment". ${ }^{110}$ For example, a world-record $€ 222 \mathrm{~m}$ spent on the Neymar transfer in 2017 has opened discussions regarding whether clubs can use loopholes in the system to circumvent FFP. ${ }^{111}$ Furthermore, another mitigating factor is that the break-even rule, does not strictly apply to certain categories of expenditure such as infrastructure improvement and youth training. ${ }^{112}$

The case of FFP shows that public orders once again refused to intervene directly into the matters of the private order. FFP is the result of a procedural approach that public orders increasingly take towards FIFA's private order by assisting dialogue among interested stakeholders. The new procedural approach plays a central role in these interactions and is gradually becoming the main mechanism that public orders, and predominantly the EU, use to mitigate disbalances of private ordering.

\subsubsection{Social dialogue and the rising procedural approach}

The examples of third-party player ownership and FFP indicate that while the EU does not intervene directly, it remains actively involved in the process of the inclusion of the EU policy, predominantly via the EU Commission, into

\footnotetext{
$\overline{109}$ Craven (2014).

110 Flanagan (2017) The Evolution of UEFA's Financial Fair Play Rules-Part 2: the legal challenges asser international sports law blog. http://www.asser.nl/SportsLaw/Blog/post/the-evolution-of-uefas-financial-fair-play-rules-part-2-the-legal-challenges-by-christopherflanagan. Accessed 26 Jan 2018.

111 Perchstone and Grayes (2017) UEFA's financial fair play ruleswhy it barks but cannot bite. Monday. http://www.mondaq.com/ Nigeria/x/655756/Sport/UEFAs +Financial+Fair+Play+Rules+ Why+It+Barks+But+Cannot+Bite. Accessed 26 Jan 2018.

112 Joint Statement supra note 108, para 6.
}

the football rules. In this context, social dialogue has been increasingly important instrument. Since Bosman, the Commission's focus has shifted from the design of the rules to the procedure of rule-making. ${ }^{113}$ Accordingly, this provides a better chance that football regulations take into account the interests of all interested actors and that are better aligned with the fundamental values of democratic public orders. State-backed efforts to facilitate dialogue with the aim of promoting inclusive rule-making within a private order is the softest version of interactions between public and private orders.

The recent social dialogue in European football, brokered by the European Commission, illustrates how public orders can use this procedural mechanism to fulfill their role as guardians of private orders. The problem arose from reported widespread practices of abusing player rights in some Eastern European countries, including cases of imposing penalties on players equal to their salary or not paying salaries to injured players. ${ }^{114}$ Such instances suggest that clubs may have tilted the balance in their favor and football authorities failed to correct the situation. Although this is a case justifying public intervention, the European Commission, instead of intervening directly and regulating sports, encouraged various stakeholder groups, such as the European Club Association and FIFPro, which represent the interests of clubs and players, respectively, to engage in a dialogue with a view to improving the practices of player protection. ${ }^{115}$ Both groups had equal representation in the dialogue. The process resulted in the establishment of the European Sectoral Social Dialogue Committee in the Professional Football Sector and a document listing the minimum requirements in standard players' contracts in Europe. ${ }^{116}$ The European Commissioner for Employment, Social Affairs and Inclusion was responsible for the social dialogue and the European Commission promises to assist in the monitoring and implementation of the Agreement. ${ }^{117}$

113 Commission of the European Union, White Paper on Sport, COM (2007) 391 Final, July 2007, pp. 18-19. http://eur-lex.europa.eu/legalcontent/EN/TXT/PDF/?uri=CELEX:52007DC0391\&from=EN.

Accessed 26 Jan 2018. (introducing the idea of organizing social dialogue among various stakeholder groups in sports to address the common concerns of employers and athletes and improve working conditions in accordance with the EU standards).

114 Colucci and Geeraert (2011), p. 64.

115 Ibid, pp. 60-67.

116 See Agreement Regarding the Minimum Requirements for Standard Player Contracts in the Professional Football Sector in European Union and the Rest of the UEFA Territory, April 2012. http://ec.europa.eu/social/BlobServlet?docId=7678\&langId=en. Accessed 11 Jan 2018.

117 EU Commission News: new agreement on contract rights for footballers, April 2012. http://ec.europa.eu/social/main.jsp?catId= $89 \&$ langId=en\&newsId $=1279 \&$ furtherNews=yes. Accessed 11 Jan 2018. 
Yet, the Agreement, indeed, has not been implemented very diligently and the effectiveness of the procedure raises many questions. ${ }^{118}$ Despite the fact that outcomes of the social dialogue may not have met expectations, it is, in principle, the right procedure. By promoting the social dialogue, the European Commission tried to achieve balance in the involvement of various interest groups in football governance and at the same time preserve the autonomy and self-regulation of football. The European Commission's role in the social dialogue was active as far as the general direction of the rules is concerned. In the negotiations itself, however, its role was rather passive and boiled down to the role of a powerful moderator; the interest groups were the ones that designed the rules. ${ }^{119}$ This is in stark contrast to the earlier case of designing transfer rules where interest groups, like FIFPro, although present, had only minimal input in the design of the rules. It was the task of the European Commission to negotiate actively and promote the interests of weaker parties. For the private order, participation in the social dialogue and support in implementing the results of this dialogue is the best way to guarantee its role as a supplier of rules. ${ }^{120} \mathrm{In}$ other words, while the social dialogue can be improved to ensure better outcomes, procedure-wise, the dialogue is the solution.

As a reward, FIFA offers common rules of behavior spanning across borders that are tailored to the needs of the involved parties, promote predictable contractual relations, and create incentives to invest in training young players. ${ }^{121}$ These advantages would be lost if public interventions removed FIFA's order and replace it by a patchwork of national laws, unstable contractual relations, more costly dispute resolution and enforcement mechanisms, and limited ability to encourage talent development. ${ }^{122}$ In contrast, however, the private order's refusal to accommodate such efforts of public orders might undermine the order by giving incentives to interest groups to advocate for external state involvement or litigate in state courts, thereby putting an end to the regulatory monopoly of FIFA's private order. The following section illustrates this. Not cleaning the

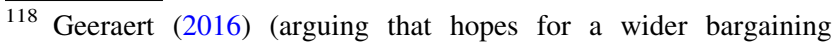
agreement in professional football are currently not realistic). See also Parrish (2016).

119 According to our model, even if the Commission would be more active in designing the rules, it would still be beneficial than nonaction. This is because such opportunistic behavior within social dialogue of equal parties cannot destabilize the entire systems of private orders, to the opposite, overall, these interactions can strengthen private orders, rather than weaken them.

120 Colucci and Geeraert (2011), p. 67.

121 Duval (2016), pp. 81-116 (discussing public-private nature of FIFA regulation).

122 See Gomtsian (2017).
}

house even after public interventions such as the FIFAgate, may lead to a forceful, but legitimate, public intervention with possibly tragic consequences for the world of football.

\subsection{How rotten private orders invite a reversed civil society to intervene}

While FIFA's order has many advantages, at some point, it seemed that FIFA is so powerful that it does not have to account to anyone. ${ }^{123}$ Along with the increasing commercial dimension, serious financial integrity weaknesses, as well as corruption scandals, the incentives of states and other public orders, particularly the EU, to intervene have grown. ${ }^{124}$ For corrupt sport officials, for example, FIFA has long been a popular place. But some states are getting tougher on such ruses. The US and Swiss enforcement authorities, for example, hope that the imposition of strict anti-corruption laws, often applied to conduct occurring outside their territorial jurisdiction, will make it easier to limit the loot of crooked bureaucrats. Furthermore, intensive interactions between FIFA and public orders can also be seen in the areas of fundamental rights and competition. ${ }^{125}$ In this context, both FIFA, by its reluctance to face some of these problems, and public orders, by overreacting in certain cases, can contribute to the disintegration of the entire system.

\subsubsection{The FIFA-gate scandal}

FIFA-Gate is a major foreign anti-corruption enforcement scheme. The scheme exemplifies how public orders intervene in private orders when a private order evolves into an enterprise with elitist structures that extensively tunnel the private orders' wealth at the expense of all others. While FIFA is in principle a non-profit organization, from 2011 to 2014 FIFA generated revenue of $\$ 5.718$ billion, compared to $\$ 2.2$ billion in expenses, mainly as the result of selling the television and marketing rights to the 2014 World Cup in Brazil. ${ }^{126}$ Despite this financial success, however, FIFA has had serious financial integrity problems including corruption and bribery related to, for example, the distribution of marketing and broadcasting rights. In the Copa América bribery scheme, one out of many bribery schemes sanctioned by the US Department of Justice, sport-marketing companies were continuously bribing influential

\footnotetext{
${ }^{123}$ See generally, Transparency International (2016).

124 Jennings (2011).

125 Among many other see, Serby (2016) (discussing how Financial Fair Play Regulation and other sporting rules breach the fundamental freedoms and competition law).

${ }^{126}$ FIFA Financial Report 2016 supra note 59.
} 
Fig. 2 Bribery in the Copa América



football officials to receive official support from these officials and acquire exclusive partnership contracts related to the football championship of South America. The bribery payments for each tournament finally reached as high as $\$ 35$ million. ${ }^{127}$ The extent of this bribery scheme, as one of approximately 15 criminal schemes sanctioned by the US authorities, is illustrated in Fig. 2 (The original source is the United States Attorney, the figure was found in Sargeant P, June 2015. Football Corruption: Who Bought the Copa America? BBC. http://www.bbc.com/news/ world-latin-america-33087370. Accessed 26 Jan 2018) below. ${ }^{128}$

FIFA-Gate illustrates that private associations, along with promoting the interests of their members, have also their own interests or the interests of the bureaucrats administering the functioning of private associations. In the discussed Copa América scheme, individuals involved in administering a private association were interested in strengthening bureaucracy to increase their importancealthough legal, this is not always in the interests of other actors-and used their power to promote their own selfinterest, often in breach of ethical standards and legal rules.

\footnotetext{
127 For more information about the process, see generally Information No. 14-cr-609, United States vs. Hawilla, Traffic Sports USA, INC., and Traffic Sports International, INC.(12 December 2014), pp. 21-40.

128 For the overview of the criminal schemes see ibid and Superseding Indictment No. 15-cr-252, United States vs. Hawit et al., No. 15-cr-252 (25 November 2015).
}

Clearly, powerful inside interest groups disbalanced the functioning of FIFA's order and used it to serve their own interests rather than the interests of football stakeholders. $^{129}$

In these settings, despite diplomatic protests of other countries, such as Russia, that the investigation against FIFA's officials is illegal extraterritorial use of US law, the US authorities structured the entire FIFA enforcement actions as a broad conspiracy, criminal enterprise, based on the Racketeer Influenced and Corrupt Organization Act (RICO). ${ }^{130}$ The US authorities stated: "After decades of [...] brazen corruption, organized soccer needs a new start-a new chance for its governing institutions to provide honest oversight and support of a sport [...]"131 Following the US charges in May 2015, FIFA's new top bureaucrats tried to use the 2015 charges to their advantage and started, while portraying themselves as agents of an

\footnotetext{
${ }^{129}$ See the discussion about elitists groups in Sect. 3.1 above.

130 Section 901(a) of the Organized Crime Control Act of 1970, Public Law No. 91-452, 18 U.S.C. $\S \S 1961-1968$; Foreign Policy, May 2015. Russia: US FIFA Investigation is Illegal Extraterritorial Use of Law. http://foreignpolicy.com/2015/05/27/russia-u-s-fifa-inves tigation-is-illegal-extraterritorial-use-of-law-world-cup-2018-seppblatter-putin/. Accessed 26 Jan 2018.

131 United States Department of Justice, May 2015. Nine FIFA Officials and Five Corporate Executives Indicted for Racketeering Conspiracy and Corruption. Press Release. https://www.justice.gov/ opa/pr/nine-fifa-officials-and-five-corporate-executives-indicted-rack eteering-conspiracy-and. Accessed 26 Jan 2018.
} 
integrity reform, engaging in similar activities as their predecessors. ${ }^{132}$ Only 6 months later, sixteen additional FIFA officials, some of them the highest FIFA officials that replaced the old leadership, were charged with a 92-count "superseding indictment" that was even bigger than the original indictment. ${ }^{133}$

\subsubsection{The effect of FIFA-gate}

Global application of US criminal legislation illustrates how private orders with elitist structures face external pressure to improve their governance. The illustrated practice of states, though controversial in many respects, has been a crucial element in ensuring that one of the groups within FIFA's order is not tilting the balance too much in its own favor. This is exactly the case when the state can help to strengthen private orders. By reigning too powerful actors, public orders can contribute to the success of a private order. Otherwise, a private order might turn into an association that promotes the interests of only one group, at the expense of all others, losing broad support and transferring value from one to another group instead of creating economic value.

In the discussed case, not only many of the highest FIFA officials resigned their functions, but also pleaded guilty to number criminal offenses. ${ }^{134}$ Following the extraordinary FIFA congress that adopted landmark reforms in February 2016, FIFA implemented governance reforms. Be it the separation of strategic functions from executive functions, stronger control of money flows, or enhanced transparency, FIFA has been given a chance to become less of a rotten order than it used to be before the US criminal enforcement actions. ${ }^{135}$ The allegations brought by the US and other authorities against FIFA officials and marketing corporations can help FIFA to clean its house and prevent greater interventions that may undermine the existence of FIFA's order and remove its advantages. ${ }^{136}$

However, a private association may reach a stage when there is no way back. If norms of private ordering become

\footnotetext{
$\overline{132 \text { Paragraph }} 136$ et seq. of the Superseding Indictment supra note 128.

133 Ibid.

134 Defendants in the original indictment were citizens of ten different countries.

135 FIFA, October 2016. FIFA 2.0: The Vision for the Future. http:// resources.fifa.com/mm/document/affederation/bodies/02/86/83/93/one year_extraordinarycongress_neutral_neutral.pdf. Accessed 26 Jan 2018.

136 This logic applies not only to corruption but also to many other aspects of FIFA's order. Consider, for example, the discussion on procedural fairness and transparency related to the CAS dispute resolution mechanism. The fact that CAS has problems does not mean that the mechanisms, or its leading features, should be abolished. Similarly, FIFA's governance problems do not imply that FIFA's order is in its essence undesirable.
}

so corrupt that a positive change is hardly possible, direct public intervention is desirable. After the recent neutralization of FIFA's internal corruption investigations, more radical "public nudge" may be needed to wake up FIFA before it is too late. The reluctance of FIFA to improve its governance may invite the reverse civil society to impose "certain basic "constitutional' requirements". ${ }^{137}$ There is, however, a very thin line between such constitutional requirements and other interventions that may remove the advantages if FIFA's order.

\section{Conclusion}

The evidence of private institutions that, relatively independently, support order under the ever-present influence of public orders indicates that the division between "purely" public and "purely" private modes of governance is a well-conceptualized illusion. This illusion poses the risk in that sticking too much to the traditional publicprivate divide could develop doubts about the ability of researchers to say something useful as far as the emergence and evolution of good order is concerned. Maybe surprisingly, this concern unites both the legal-centric scholars and fans of economic governance research programs. Both camps are too radical in their belief of who should be in charge of establishing a good order: "some scholars want to see self-regulation and privatization everywhere, while others simply want to see the State still being in control, and both are somehow right". 138

The success of modern private orders, including FIFA, is closely associated with the constraints provided by public orders. To grasp the nature of these constraints we considered the role of the state to be similar to a democratic process in which the civil society influences public decision-making. Public orders may protect private orders, in the same way that civil society protects states, from the capture of such private orders by inside interest groups. In this context, FIFA exemplifies two main roles that public orders play in the evolution of successful private orders. In their first role, public orders authoritatively change, limit, or even prohibit certain functions of private orders. Common rules spanning across borders, predictable contractual relations, and incentives to invest in training young players,

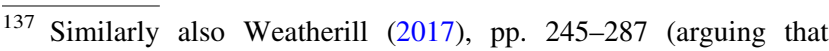
increasing concern to consider the claim that sport is special not just in the context of substance but also in terms of the specificity of governance choices of sport governing bodies); Duval A, May 2017. The reform of FIFA: plus ça change, moins ça change? Asser International Sports Law Blog. http://www.asser.nl/SportsLaw/Blog/ post/the-reform-of-fifa-plus-ca-change-moins-ca-change. Accessed 26 Jan 2018.

138 Calliess and Zumbansen (2010), p. 113.
} 
are only some advantages that convinced public orders to allow FIFA to develop its tailored rules of behavior. These advantages would not be utilized without public orders granting regulatory privileges to FIFA, or would be lost if public interventions removed FIFA's order and replace it by a patchwork of national laws, unstable contractual relations, more costly dispute resolution and enforcement mechanisms, and limited ability to encourage talent development.

In their second role, public orders act alongside private orders. For example, when co-determining the substance of institutions in a regulatory space that states share with private orders. FIFA exemplifies that the public-private interactions direct the evolution of private orders by setting a starting benchmark of freedom, but then stepping back and letting private ordering function within such benchmark. In some cases, a public order acts as an equal partner and protects private orders, in the same way as civil society protects states, from the capture of such private orders by inside interest groups. From this perspective, FIFA is a success story of public-private interaction.

The fact that FIFA is predominantly constrained by reversed civil society, i.e., the state, increases FIFA's responsibility towards the public. The public is in a position to blame FIFA, rather than blame the state, for ignoring the problem of negative externalities and weak governance. If FIFA cannot address some of these problems sufficiently, it is inviting the state to return in its authoritative role, thereby undermining FIFA's own authority. The primary reason for potential state intervention, however, is the private order rules, but internal imbalances that undermine the legitimacy of its constituency. These imbalances may also corrupt the norms of the private order. The strongest form of reversed civil society's intervention to restore the lost balance is to strike against the corrupt constituency. For the time being, FIFAgate represents a moderate strike by reversed civil society. Nevertheless, a moderate strike that does not lead to improvements can easily evolve into a revolution.

Acknowledgements We benefited from discussions with Annemarie Balvert, Jose Caiado, Antoine Duval, Tom Ellis, Oğuz Kirman, Mislav Mataija, Phillip Paiment, and an ex-legal counsel at a FIFA member association. We wish to thank the Article's anonymous reviewer and the Volume 17 editors of the International Sports Law Journal for useful suggestions and thoughtful comments and we wish to thank the organizers and participants for their useful comments and suggestions.

Open Access This article is distributed under the terms of the Creative Commons Attribution 4.0 International License (http://creative commons.org/licenses/by/4.0/), which permits unrestricted use, distribution, and reproduction in any medium, provided you give appropriate credit to the original author(s) and the source, provide a link to the Creative Commons license, and indicate if changes were made.

\section{References}

Acemoglu D, Robinson J (2005) Economic origins of dictatorship and democracy. Cambridge University Press, Cambridge

Acemoglu D, Robinson J (2012) Why nations fail?. Crown Business, New York

Bernstein L (1992) Opting out of the legal system: extralegal contractual relations in the diamond industry. J Leg Stud 21:115-157

Bernstein L (2001) Private commercial law in the cotton industry: creating cooperation through rules, norms, and institutions. Mich Law Rev 99:1724-1790

Cafaggi F (2012) Transnational private regulation and the production of global public goods and private 'bads'. Eur J Int Law 23:695-718

Cafaggi F, Iamiceli P (2014) Supply chains, contractual governance and certification regimes. Eur J Law Econ 37:131-173

Calliess G-P, Zumbansen P (2010) Rough consensus and running code: a theory of transnational private law. Hart Publishing, Oxford

Claire Cutler A (2010) The legitimacy of private transnational governance: experts and the transnational market for force. Soc Econ Rev 8:157-185

Colucci M, Geeraert A (2011) Social dialogue in European professional football. Int Sports Law Js 15:56-67

Cooter RD, Ulen TS (2012) Law and economics. Addison-Wesley, Boston

Craven R (2014) Football and state aid: too important to fail? Int Sports Law Js 14:205-217

Czarnota PA (2013) FIFA transfer rules and unilateral termination without "just cause". Berkeley J Entertain Sports Law 2:1-47

de Búrca G, Keohane R, Sabel Ch (2014) Global experimentalist governance. Br J Politic Sci 44:477-486

de Wagen FM (2011) Webster, Matuzalem, De sanctis. and the future. Int Sports Law J 15:42-56

Delimatsis P (2017) The future of transnational self-regulationenforcement and compliance in professional services. Hastings Int Comp Law Rev 40:1-68

Dixit AK (2004) Lawlessness and economics: alternative modes of governance. Princeton University Press, Princeton, pp 32-48

Duval A (2015) The court of arbitration for sport and EU law: chronicle of an encounter. Maastricht $\mathrm{J}$ Eur Comparat Law 22:224-255

Duval A (2016) The FIFA regulations on the status and transfer of players: transitional law-making in the shadow of Bosman. The legacy of Bosman: revisiting the relationship between EE law and sport. Springer, Berlin, pp 87-116

Duval A, Van Rompuy B (2016) Introduction. The legacy of bosman: revisiting the relationship between EE law and sport. Springer, Berlin, pp 1-12

Ellickson RC (2016) When civil society uses an iron fist: the roles of private associations in rulemaking and adjudication. Am Law Econ Rev 18:235-271

Geeraert A (2016) The European sectoral social dialogue committee in professional football: power relations, legitimacy and control. Soccer Soc 16:98-115

Geey D (2016) Third party investment from a UK perspective. In: Debating FIFA's TPO Ban: ASSER International Sports Law Blog Symposium. Int Sports Law J 15:245-251

Gibbons R, Henderson R (2012) Relational contracts and organizational capabilities. Organ Sci 23:1350-1364

Gomtsian et al (2017) Between the green pitch and the red tape: the private legal order of FIFA. Yale J Int Law 43, forthcoming 
Greif A (1993) Contract enforceability and economic institutions in early trade: the Maghribi Traders' coalition. Am Econ Rev 83:525-548

Greif A (2006) Institutions and the path to the modern economy. Cambridge University Press, New York

Hadfield GK, Weingast BR (2012) What is law? A coordination model of the characteristics of legal order. J Legal Anal $4: 471-514$

Hansmann H (2000) The ownership of enterprise. Harvard University Press, Cambridge

Ip EC (2011) Globalization and the future of the law of the Sovereign state. Int J Const Law 8:636-655

Jennings A (2011) Investigating corruption in corporate sport: the IOC and FIFA. Int Rev Sociol Sport 46:387-398

Kaldor M (2003) The idea of global civil society. Int Aff 79:583-593

Katz A (1996) Taking private ordering seriously. Univ Pa Law Rev 144:1745-1763

Koyama M (2012) Prosecution associations in industrial revolution England: private providers of public goods? J Legal Stud 41:95-130

La Liga (2016) FIFA must regulate TPO, not ban it. In: Debating FIFA's TPO Ban: ASSER International Sports Law Blog Symposium. International Sports Law Journal 15: 235-238

Larrain M, Prüfer J (2015) Trade associations, lobbying, and endogenous institutions. J Leg Anal 7:467-516

Leeson PT (2009) The invisible hook: the hidden economics of pirates. Princeton University Press, Princeton

Leisinger KM (2009) The role of corporations in shaping globalization with a human face. In: Straus J (ed) The role of law and ethics in the globalized economy. Springer, Berlin, pp 1-19

Libecap GD (1989) Contracting for property rights. Cambridge University Press, Cambridge

Lindholm J (2016) Can I please have a slice of ronaldo? The legality of FIFA's ban on third-party ownership under European union law. Int Sports Law J 15:137-148

Masten SE, Prüfer J (2014) On the evolution of collective enforcement institutions: communities and courts. J Leg Stud 43:359-400

Mataija M (2016) Private regulation and the internaarket: sports, legal services, and standard setting in EU economic law

McMillan J, Woodruff Ch (2000) Private order under dysfunctional public order. Mich Law Rev 98:2421-2458

Meier HE, Garcia B (2015) Protecting private transnational authority against public intervention: FIFA's power over national governments. Public Adm 93:890-906

Milhaupt CJ, West MD (2000) The dark side of private ordering: an institutional and empirical analysis of organized crime. Univ Chic Law Rev 61:41-98

Mitra A (2015) An Ethical analysis of the 2014 FIFA world cup in Brazil. Law Bus Rev Am 21:3-19

Noland M (2016) The North Korean famine. In: Seth MJ (ed) Routledge handbook of modern Korean history. Routledge, Abingdon, pp 234-245

North DC (1991) Institutions. J Econ Perspect 5:97-112

North DC et al (2009) Violence and social orders: a conceptual framework for interpreting recorded human history. Cambridge University Press, Cambridge
Nye JS Jr, Keohane RO (1971) Transnational relations and world politics: an introduction. Int Organ 25:329-349

Ogilvie S, Carus AW (2014) Institutions and economic growth in historical perspective. Handbook of economic growth. Elsevier, Amsterdam, pp 403-503

Parrish R (2016) The European social dialogue: a new model of governance for European football? The legacy of Bosman: revisiting the relationship between EE law and sport. Springer, Berlin, pp 187-211

Pielke R (2013) How can FIFA be held accountable? Sport Manag Rev 16:255-267

Poli R (2016) Third-party entitlement to shares of transfer fees: problems and solutions. In: Debating FIFA's TPO Ban: ASSER International Sports Law Blog Symposium. Int Sports Law J $15: 238-242$

Posner EA (1996) Law, economics, and inefficient norms. Univ $\mathrm{Pa}$ Law Rev 144:1697-1744

Ranchordas S (2015) Does sharing mean caring? Regulating innovation in the sharing economy. Minn JL Sci Tech 16:413-475

Reck AN (2016) The impact of the TPO ban on South American football. In: Debating FIFA's TPO Ban: ASSER International Sports Law Blog Symposium. Int Sports Law J 15:242-245

Richman BD (2009) The antitrust of reputation mechanisms: institutional economics and concerted refusals to deal. Va Law Rev 95:325-387

Rose-Ackerman S (2011) Anti-corruption policy: can international actors play a constructive role? 440 Yale Law Econ Res Pap

Schofer E, Longhofer W (2011) The structural sources of association. Am J Sociol 117:539-585

Scholte JA (2004) Civil society and democracy in global governance. Gov Oppos 39:281-304

Serby T (2016) The state of EU sports law: lessons from UEFA's 'Financial Fair Play' regulations. Int Sports Law J 16:37-51

Skocpol $\mathrm{T}$ et al (1986) Bringing the state back in. Cambridge University Press, Cambridge

Szyszczak E (2007) Is sport special? In: Bogusz B, Cygan AJ, Szyszczak E (eds) The regulation of sport in the European Union. Elgar Edward, Cheltenham, pp 3-32

Tirole J (1996) A theory of collective reputations (with applications to the persistence of corruption and to firm quality). Rev Econ Stud 63:1-22

Transparency International (ed) (2016) Global corruption report: sport. Routledge, Abingdon

Tudor D, Pearson J (2015) North Korea confidential: private markets, fashion trends, prison camps, dissenters and defectors. Tuttle Publishing, Clarendon

Weatherill SR (2017) Principles and practices in EU sports law. Oxford University Press, Oxford

Williams B (2009) The fate of third party ownership of professional footballers' rights: is a complete prohibition necessary? Texas Rev Entertain Sports Law 10:79-101

Williamson OE (2005) The economics of governance. Am Econ Rev 95:1-18 